\title{
Presence of Prochlorococcus in the aphotic waters of the western Pacific Ocean
}

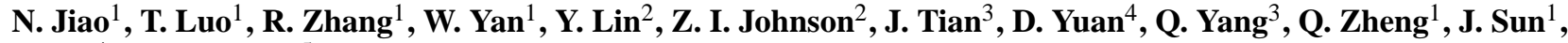 \\ D. $\mathrm{Hu}^{4}$, and P. Wang ${ }^{5}$ \\ ${ }^{1}$ State Key Laboratory of Marine Environmental Science, Xiamen University, Xiamen 361005, China \\ ${ }^{2}$ Marine Laboratory, Nicholas School of the Environment, Duke University, Beaufort 28516, North Carolina, USA \\ ${ }^{3}$ Physical Oceanography Laboratory, Ocean University of China, Qingdao 266100, China \\ ${ }^{4}$ Institute of Oceanology, Chinese Academy of Sciences, Qingdao 266071, China \\ ${ }^{5}$ State Key Laboratory of Marine Geology, Tongji University, Shanghai 200092, China
}

Correspondence to: N. Jiao (jiao@xmu.edu.cn)

Received: 17 May 2013 - Published in Biogeosciences Discuss.: 12 June 2013

Revised: 12 February 2014 - Accepted: 13 February 2014 - Published: 29 April 2014

\begin{abstract}
Prochlorococcus, the smallest but most abundant marine primary producer, plays an important role in carbon cycling of the global ocean. As a phototroph, Prochlorococcus is thought to be confined to the euphotic zone, with commonly observed maximum depths of $\sim 150-200 \mathrm{~m}$, but here we show for the first time the substantial presence of Prochlorococcus populations in the dark ocean ("deep Prochlorococcus" hereafter). Intensive studies at the Luzon Strait in the western Pacific Ocean show that the deep Prochlorococcus populations are exported from the euphotic zone. Multiple physical processes including internal solitary waves could be responsible for the transportation. These findings reveal a novel mechanism for picoplankton carbon export other than the known mechanisms such as sinking of phytodetritus and aggregates or grazing-mediated transportation.
\end{abstract}

\section{Introduction}

Prochlorococcus, the smallest known oxygenic phototroph, is the numerically dominant primary producer (typically $10^{4}-10^{5}$ per $\mathrm{ml}$ ) between $40^{\circ} \mathrm{N}$ and $40^{\circ} \mathrm{S}$, and contributes significantly to total primary productivity in the vast oligotrophic oceans (Partensky et al., 1999; Coleman and Chisholm, 2007; Partensky and Garczarek, 2010). Unlike other primary producers, Prochlorococcus does not sink, due to its small size $(0.5-0.7 \mu \mathrm{m}$ in diameter) and neutral buoyancy. Thus, the tremendous amount of carbon fixed by Prochlorococcus had been generally regarded as being consumed through the microbial loop and recycled within the euphotic zone. However, a recent model analysis suggested that a significant fraction of carbon export may be attributed to picoplankton despite their lack of direct sinking (Richardson and Jackson, 2007). The known picoplankton export mechanisms include aggregation (Jackson et al., 2005), particle packing through grazing and egestion (Richardson and Jackson, 2007), phytodetritus (Lochte and Turley, 1988) as well as winter ventilation (Vilibić and Šantić, 2008). In practice, the previously observed picoplankton exported to the deep sea are mainly Synechococcus, and more rarely picoeukaryotes (Lochte and Turley, 1988; Vanucci et al., 2001; Sohrin et al., 2011). Synechococcus are reported to be able to utilize organic substrates (Moore et al., 2002; Glibert et al., 2004), and thus thought to be able to survive in the dark (Cottrell and Kirchman, 2009; Sohrin et al., 2011). In the case of Prochlorococcus, although previous molecular analysis revealed the existence of its functional genes in aphotic waters in the North Pacific subtropical gyre area (DeLong et al., 2006) and Sargasso Sea (Martinez et al., 2012), abundant Prochlorococcus populations are thought to be confined to the euphotic zone (Partensky et al., 1999; Coleman and Chisholm, 2007; Partensky and Garczarek, 2010). Here we report for the first time the substantial presence of Prochlorococcus populations in the dark ocean (hereafter "deep Prochlorococcus"). During our investigations from 
2008 to 2012, we frequently observed intact Prochlorococcus cells in the mesopelagic waters in the western Pacific Ocean and its marginal seas. Based on biological and physical oceanographic observations and analysis, we propose here a novel mechanism for export of Prochlorococcus to the ocean interior, which sheds new light on our understanding of carbon cycling and carbon sequestration in the ocean and points to additional areas where further studies are needed.

\section{Materials and methods}

\subsection{Cruises and sampling}

Seven cruises to the western Pacific Ocean, northern South China Sea, and Luzon Strait were conducted from 2008 to 2012 (Table 1). Water samples were collected at various depths from the surface to $2000 \mathrm{~m}$ using $12 \mathrm{~L}$ Niskin bottles mounted on a CTD-carousel sampler. Standard sampling procedures were followed (Sohrin et al., 2011) and the temperature, salinity and $\mathrm{pH}$ of the sampled water in the Niskin bottles were monitored to ensure no contamination from the surface water to the deep water samples. Subsamples $(15 \mathrm{ml})$ were collected immediately for onboard flow cytometry analysis. Aliquot samples were fixed with glutaraldehyde (final concentration $0.5 \% \mathrm{v} / \mathrm{v}$ ), flash frozen in liquid nitrogen and stored at $-80^{\circ} \mathrm{C}$ until later flow cytometric analysis in the laboratory.

For phylogenetic analysis, $2 \mathrm{~L}$ of seawater were filtered onto $0.22 \mu \mathrm{m}$ pore-size $47 \mathrm{~mm}$-diameter polycarbonate filters (Millipore, Bedford, MA, USA) to retrieve the total picoplanktonic population. The filters were stored at $-80^{\circ} \mathrm{C}$ until genomic DNA extraction. For cellular ribosomal RNA content analysis, $100 \mathrm{ml}$ (depths $<200 \mathrm{~m}$ ) or $200 \mathrm{ml}$ (depths $>=200 \mathrm{~m}$ ) of seawater were filtered onto a $0.22 \mu \mathrm{m}$ poresize $25 \mathrm{~mm}$-diameter polycarbonate filter under low vacuum ( $>-0.3$ bar). To preserve DNA for qPCR, filters were stored at $-80^{\circ} \mathrm{C}$ until DNA extraction. To preserve RNA for RTqPCR, each filter was immersed in $600 \mu \mathrm{l}$ of an RLT solution (Qiagen, Chatsworth, CA, USA) containing $1 \% \beta$ mercaptoethanol and stored at $-80^{\circ} \mathrm{C}$ until RNA extraction.

\subsection{Flow cytometry (FCM) analysis}

Prochlorococcus and other picoplankton (Synechococcus, heterotrophic bacteria/archaea, picoeukaryotes and viruses) were analyzed using an onboard FACSAria flow cytometer (Becton, Dickinson and Company, USA) equipped with a $488 \mathrm{~nm}$ laser as the excitation light source, following procedures described previously (Marie et al., 1999). Negative controls such as sheath water, filtered seawater and even condensed deep seawater samples were applied in addition to FCM "backflush" to get rid of tubing memory effects between samples (Figs. S1 and S2). At each station, in order to ensure the elimination of potential contamination by epipelagic Prochlorococcus populations, we always run the deep water samples first and then move on upward. All onboard FCM observations were confirmed by another flow cytometer (EPICS Altra II; Beckman Coulter, USA) in the laboratory. In both flow cytometry analyses, BD Trucount control beads were used to calibrate the flow rate to achieve accurate enumeration of the cells.

\subsection{Molecular analysis}

Environmental genomic DNA was extracted by using the phenol-chloroform method (Fuhrman et al., 1988). The quantity and quality of DNA were evaluated by NanoDrop (Thermo Scientific). Cyanobacterial 16S-ITS-23S rRNA gene (ITS hereafter) fragments were amplified with primers Picocya16S-F (TGGATCACCTCCTAACAGGG) and Picocya23S-R (CCTTCATCGCCTCTGTGTGCC) (Cai et al., 2010). The cycling program included 8 touch-down cycles at $94{ }^{\circ} \mathrm{C}$ for $30 \mathrm{~s}, 58-54{ }^{\circ} \mathrm{C}$ for $50 \mathrm{~s}\left(-0.5^{\circ} \mathrm{C} /\right.$ cycle $)$ and $72^{\circ} \mathrm{C}$ for $1 \mathrm{~min}, 20$ normal cycles at $94^{\circ} \mathrm{C}$ for $30 \mathrm{~s}, 55^{\circ} \mathrm{C}$ for $50 \mathrm{~s}$ and $72^{\circ} \mathrm{C}$ for $1 \mathrm{~min}$, and a $7 \mathrm{~min}$ extension step. The PCR products were purified using the QIAquick Gel Extraction Kit (QIAGEN, Hilden, Germany), and cloned using the TOPO TA cloning kit (Invitrogen, Carlsbad, CA, USA) following the manufacturer's instructions. All sequences obtained were carefully checked for chimeric artifacts using the BLASTN program (http://www.ncbi.nlm.nih.gov/BLAST), and chimeric sequences were excluded. Phylogenetic analysis based on ITS sequences was carried out using MEGA 5 (Tamura et al., 2007) with the inputted alignment created by Clustal X2 (Larkin et al., 2007). The neighbor-joining and maximum likelihood phylogenetic tree were rooted from an ITS sequence of Synechococcus (WH5701) and constructed with representative ITS sequences of major Prochlorococcus ecotypes (MIT9515, MED4, MIT9215, MIT9202, MIT9312, MIT9301, AS9601, NATL1A, NATL2A, SS120, MIT9211, MIT9303, MIT9313) and environmental sequences from previous investigations (Huang et al., 2011; Martiny et al., 2009; Lavin et al., 2010) as references. The ITS sequences obtained in this study were deposited in the GenBank under accession numbers JN382571-JN383336 and KC770800-KC770987.

We quantitatively assessed the abundances (rDNA) and activities (rRNA/rDNA ratio) of two ecotypes of Prochlorococcus (high-light (HL)-adapted ecotype II and low-light (LL)adapted ecotype IV). These two ecotypes numerically dominate the upper and lower euphotic zone, respectively, in low- and mid-latitude waters (Johnson et al., 2006). Ecotype abundance was estimated using DNA-based qPCR assay as described previously (Zinser et al., 2006), with 23S rRNA primers targeting HLII (Ahlgren et al., 2006) and LLIV (Hunt et al., 2013). Ecotype specific rRNA concentration was measured by an RT-qPCR assay as described previously (Lin et al., 2013). Briefly, after bead-beating, cell lysate was diluted 1:100 in RNase-free water and used directly as a template for cDNA synthesis (iScript, Bio-Rad, Hercules, CA). The rDNA concentration, which was estimated from 
Table 1. Locations and water depths where deep Prochlorococcus were observed in the western Pacific Ocean, northern South China Sea, and Luzon Strait.

\begin{tabular}{|c|c|c|c|c|c|}
\hline Region & Date & Station & Longitude & Latitude & Deep Prochlorococcus depth (m) \\
\hline \multicolumn{6}{|c|}{ Luzon Strait and South China Sea } \\
\hline & Aug 2008 & E05 & $121^{\circ} 00^{\prime} \mathrm{E}$ & $20^{\circ} 00^{\prime} \mathrm{N}$ & $300,400,600$ \\
\hline & Aug 2008 & E04 & $121^{\circ} 00^{\prime} \mathrm{E}$ & $20^{\circ} 15^{\prime} \mathrm{N}$ & 1500 \\
\hline & Mar 2010 & LX02 & $119^{\circ} 21^{\prime} \mathrm{E}$ & $21^{\circ} 02^{\prime} \mathrm{N}$ & $300,400,500$ \\
\hline & Apr 2011 & LX01 & $117^{\circ} 51^{\prime} \mathrm{E}$ & $21^{\circ} 06^{\prime} \mathrm{N}$ & $300,400,500,700$ \\
\hline & Jul 2011 & $\mathrm{CO}$ & $122^{\circ} 18^{\prime} \mathrm{E}$ & $19^{\circ} 15^{\prime} \mathrm{N}$ & $1000,1200,1500$ \\
\hline & Jul 2011 & $\mathrm{C} 01$ & $121^{\circ} 02^{\prime} \mathrm{E}$ & $19^{\circ} 32^{\prime} \mathrm{N}$ & 300 \\
\hline & Jul 2011 & $\mathrm{C} 02$ & $121^{\circ} 00^{\prime} \mathrm{E}$ & $20^{\circ} 00^{\prime} \mathrm{N}$ & $300,500,800$ \\
\hline & Jul 2011 & $\mathrm{C} 03$ & $123^{\circ} 28^{\prime} \mathrm{E}$ & $20^{\circ} 00^{\prime} \mathrm{N}$ & 300,1000 \\
\hline & Jul 2011 & $\mathrm{~N} 22-1$ & $122^{\circ} 00^{\prime} \mathrm{E}$ & $22^{\circ} 00^{\prime} \mathrm{N}$ & 1000 \\
\hline & Jul 2011 & $\mathrm{~N} 22-4$ & $124^{\circ} 33^{\prime} \mathrm{E}$ & $22^{\circ} 00^{\prime} \mathrm{N}$ & 1000,1500 \\
\hline & Apr 2012 & DC01 & $121^{\circ} 42^{\prime} \mathrm{E}$ & $21^{\circ} 08^{\prime} \mathrm{N}$ & 300 \\
\hline \multicolumn{6}{|c|}{ Western Pacific Ocean } \\
\hline & Dec 2008 & KX08-97322 & $145^{\circ} 00^{\prime} \mathrm{E}$ & $7^{\circ} 00^{\prime} \mathrm{N}$ & 800,1500 \\
\hline & Dec 2010 & N8-12 & $133^{\circ} 42^{\prime} \mathrm{E}$ & $6^{\circ} 22^{\prime} \mathrm{N}$ & $800,1000,1500$ \\
\hline & Dec 2010 & $\mathrm{P7}$ & $129^{\circ} 59^{\prime} \mathrm{E}$ & $9^{\circ} 00^{\prime} \mathrm{N}$ & $500,800,1000,1500,2000$ \\
\hline & Jul 2011 & N5-132 & $132^{\circ} 04^{\prime} \mathrm{E}$ & $4^{\circ} 56^{\prime} \mathrm{N}$ & $600,800,1000,1200$ \\
\hline & Jul 2011 & N5-133 & $133^{\circ} 00^{\prime} \mathrm{E}$ & $5^{\circ} 00^{\prime} \mathrm{N}$ & $300,500,800,1000$ \\
\hline & Jul 2011 & N5-134 & $134^{\circ} 00^{\prime} \mathrm{E}$ & $5^{\circ} 00^{\prime} \mathrm{N}$ & 500,800 \\
\hline & Jul 2011 & N7-134 & $134^{\circ} 00^{\prime} \mathrm{E}$ & $7^{\circ} 00^{\prime} \mathrm{N}$ & $300,500,800,1000,1500$ \\
\hline & Jul 2011 & N8-6 & $129^{\circ} 00^{\prime} \mathrm{E}$ & $8^{\circ} 00^{\prime} \mathrm{N}$ & 1200 \\
\hline & Jul 2011 & P9 & $130^{\circ} 00^{\prime} \mathrm{E}$ & $6^{\circ} 30^{\prime} \mathrm{N}$ & $300,500,800,1000$ \\
\hline
\end{tabular}

qPCR assay, was subtracted from the RT-qPCR results to obtain rRNA concentration.

\subsection{Physical oceanographic observation and analysis}

In order to explore mechanisms responsible for the presence of Prochlorococcus in the aphotic deep waters, we focused on the Luzon Strait, where general physical processes including solitary waves, meso-scale eddies, interfacial Ekman transport, and turbulent mixing have been extensively investigated (Jackson and Apel, 2002; Yuan, 2002; Jia and Liu, 2004; Zhao et al., 2004b; Tian et al., 2006; Zhao and Alford, 2006; Yuan et al., 2007; Jan et al., 2007; Laurent, 2008; Jan and Chen, 2009; Tian et al., 2009; Alford et al., 2010). In our study, $75 \mathrm{kHz}$ acoustic Doppler current profilers (ADCP) were deployed to monitor internal solitary waves on the western side of the Luzon Strait $\left(21^{\circ} 00^{\prime} \mathrm{N}, 118^{\circ} 00^{\prime}-\right.$ $120^{\circ} 00^{\prime}$ E) (Fig. S3). Sea level anomalies (SLA) were also observed by satellite altimeters (Su, 2004). The turbulent dissipation rate $\varepsilon$ and mixing rate $\mathrm{K}$ are derived by applying "Thorpe scale" analysis to CTD data. The root mean square Thorpe displacement $L_{\mathrm{th}}$ for an actively mixing patch is given by $L_{\text {th }} \approx 0.8^{-1} L_{\mathrm{o}}$, where $L_{\mathrm{o}}=\left(\varepsilon / N^{3}\right)^{1 / 2}$ is the Ozmidov length scale (Dillon, 1982). $L_{\text {th }}$ can be calculated by reordering the density profile into a monotonic gravitationally stable profile. Each sample $\rho_{n}$ within the original profile is associated with a depth $z_{n}$ and in the reordered pro- file with a depth $z_{m} . L_{\text {th }}$ is defined as $L_{\text {th }}=\left(\overline{d^{\prime 2}}\right)^{1 / 2}$, where $d_{n}^{\prime}=z_{n}-z_{m}$. After $\varepsilon$ has been estimated from measured $L_{\text {th }}$ via these relationships, the mixing rates can be obtained as $K=\Gamma \varepsilon / N^{2}$, where a typical value of the mixing efficiency $\Gamma$ is 0.2 (Finnigan et al., 2002).

\section{Results and discussion}

\subsection{Abundance and phylogeny of deep Prochlorococcus in the western Pacific and its marginal seas}

Onboard flow cytometry analysis showed that Prochlorococcus was frequently present in the mesopelagic waters of the western Pacific Ocean, the Luzon Strait and the South China Sea. The FCM-characterized populations of Prochlorococcus were well defined, indicating coherent and intact populations (Fig. 1). In the western Pacific tropical and subtropical areas, deep Prochlorococcus populations were often found at depths $>1000 \mathrm{~m}$, while in the Luzon Strait and South China Sea, deep Prochlorococcus populations were mostly observed at shallower aphotic waters from $300 \mathrm{~m}$ to $500 \mathrm{~m}$ (Table 1). Taking the case of the Luzon Strait as an example for more details, the abundances of Prochlorococcus ranged from $10^{4}$ to $10^{5}$ cells $\mathrm{mL}^{-1}$ in the euphotic zone and from $\sim 10^{2}$ to $10^{4}$ cells ml ${ }^{-1}$ in the aphotic zone (Fig. 2). The maximum abundances usually occurred at around $100 \mathrm{~m}$, and 

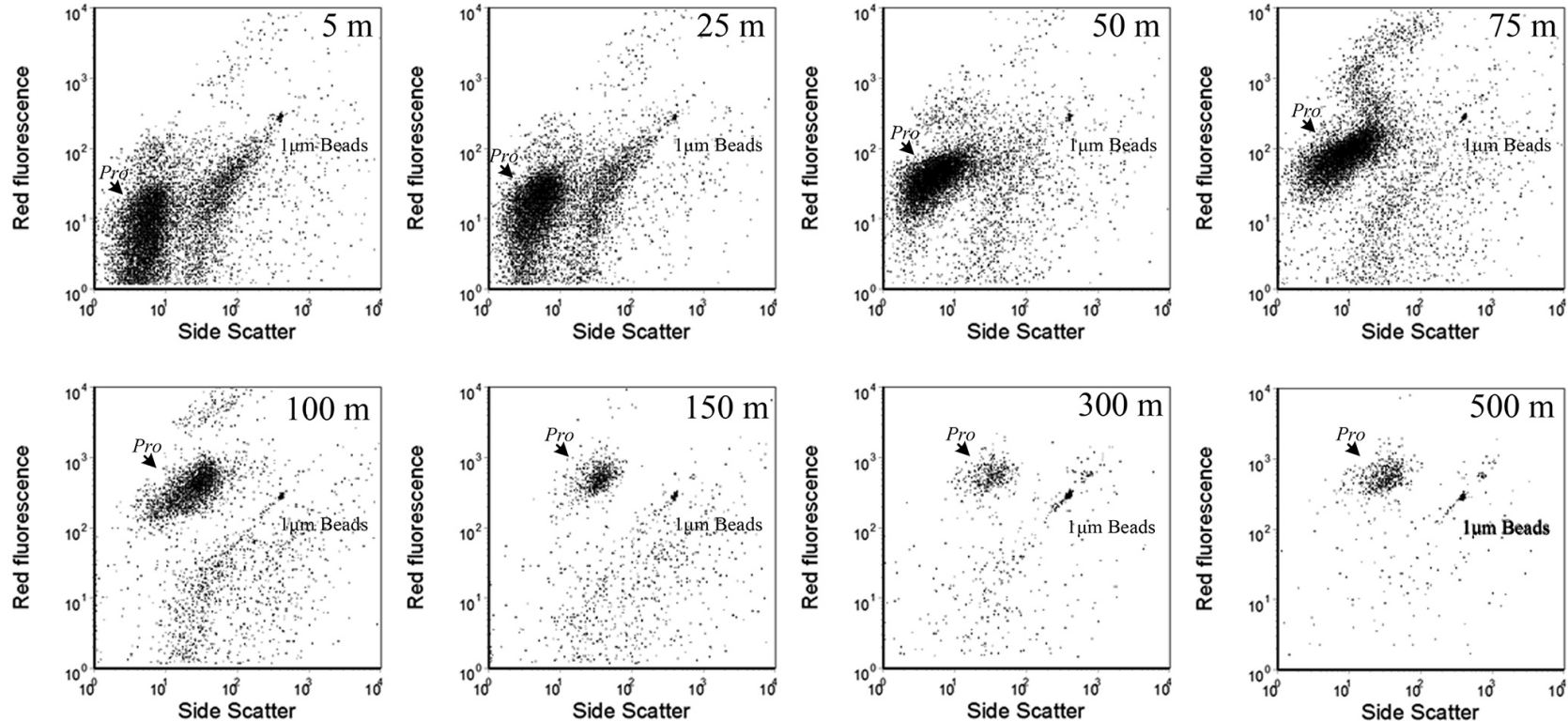

Fig. 1. Flow cytograms of Prochlorococcus samples at different water depths from the Luzon Strait (St. LX02) demonstrating the status of the Prochlorococcus populations along the water depth.

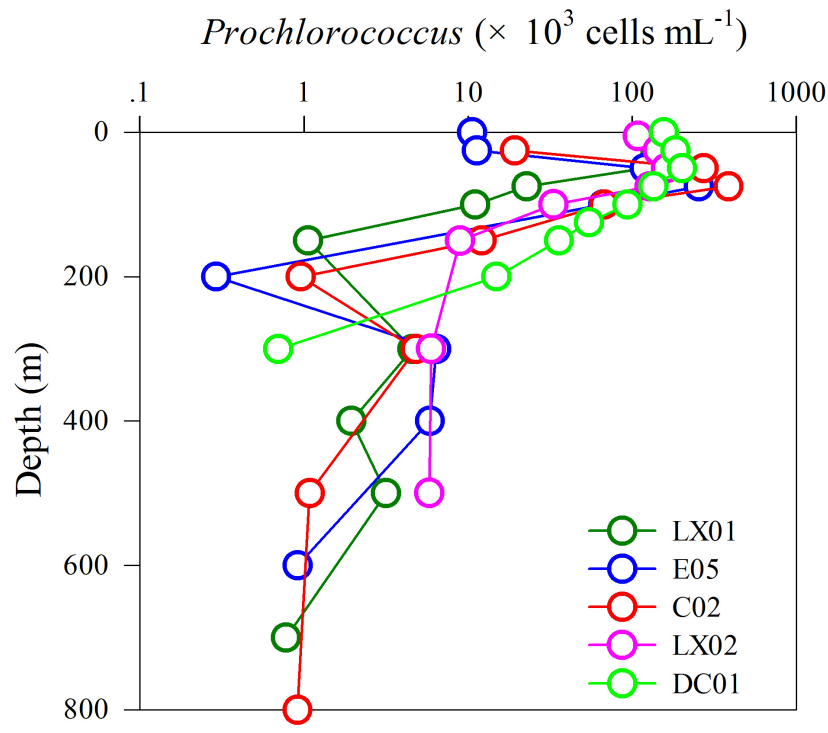

Fig. 2. Depth profile of abundance of Prochlorococcus in the Luzon Strait area, showing the presence of Prochlorococcus $\left(10^{2}-\right.$ $10^{4}$ cells $\mathrm{ml}^{-1}$ ) in the aphotic waters (below $200 \mathrm{~m}$ ).

the lowest abundances within the euphotic zone were often found at $200 \mathrm{~m}$. In the dark waters below $200 \mathrm{~m}$, the abundances of Prochlorococcus were not evenly distributed and generally decreased with depth (Fig. 2). In addition to flow cytometry enumeration, the abundances of major Prochlorococcus ecotypes (HLII and LLIV) at St. DC01 were also determined by qPCR for reference, which showed that the sums

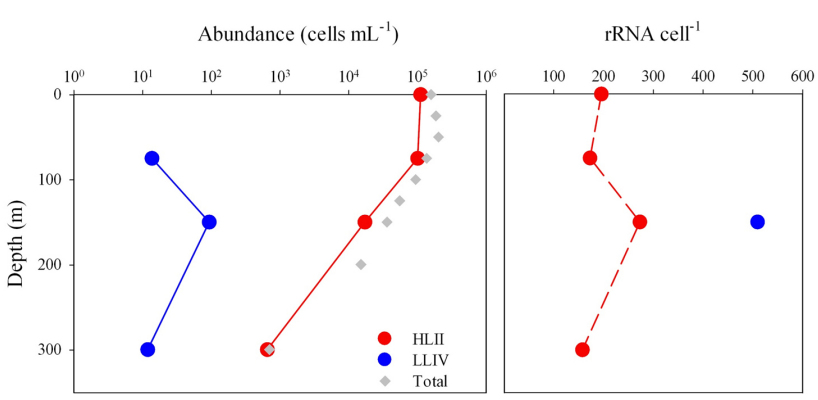

Fig. 3. Vertical profiles of (A) the abundance and (B) cell-specific rRNA content of two dominant Prochlorococcus ecotypes in the Luzon Strait area (St. DC01) determined by qPCR. Red, Prochlorococcus ecotype HLII; Blue, Prochlorococcus ecotype LLIV. The grey dots show the total Prochlorococcus abundance as determined by FCM at the same station.

of the two ecotypes were comparable to the flow cytometry results at the same station (Fig. 3a).

Phylogenetic analysis of the deep Prochlorococcus populations from the western Pacific Ocean (St. N8-12) and the Luzon Strait (St. DC01) showed that both the high-light and low-light adapted Prochlorococcus were present at all the water depths (Fig. 4). Based on clone library analysis (783 clones in total), the high-light and low-light adapted Prochlorococcus were mainly clustered in the HLII (94\% of all HL) and LLIV ( $65 \%$ of all LL) clades, respectively. Highlight adapted clades HLVI (26 clones) and HLI (4 clones) were also retrieved in our clone libraries (Fig. 4). Besides the abundant LLIV, diverse low-light lineages (LLI-III) were observed in the western Pacific Ocean and the Luzon Strait. In 
addition, 28 clone sequences were clustered into a newly discovered Prochlorococcus ecotype NC1 clade, which showed high sequence similarity with environmental sequences from the deep euphotic zone (Martiny et al., 2009). Vertically, no distinct phylogenetic differences of cyanobacterial ITS sequences were observed between samples from the euphotic and the aphotic zones (Fig. 4). These results suggest a euphotic zone source for these deep Prochlorococcus populations rather than a population unique to the aphotic environment. No novel Synechococcus clades were found in the dark ocean based on their ITS sequences (Fig. S4).

\subsection{Physiological status of Prochlorococcus in the dark ocean}

Flow cytometry fluorescence signals can be used as indicators of cellular pigment contents (Six et al., 2004). In the Luzon Strait area, the red fluorescence signals of the Prochlorococcus cells increased with increasing water depth until the bottom of the euphotic zone (150-200 m) and then declined a bit below, but were still comparable to the maximum ( $\sim 80 \%$ of the maximum). Except for the cases of $700 \mathrm{~m}$ and $800 \mathrm{~m}$, the cellular fluorescence signals of the Prochlorococcus cells at the aphotic depths were much higher than those in the upper euphotic zone (mostly 5-20\% of the maximum) (Fig. S5). In addition, the side light scatter signals (indices of cell size and cell density) of the Prochlorococcus cells in the Luzon Strait typically increased to their maximum values at the bottom of the euphotic zone (150-200 m) and then decreased gradually when depth further increased (Fig. S6), suggesting shrinks of the cell size and/or density downward.

The presence and amount of rRNA in environmental samples were used as indicators of viable Prochlorococcus populations (Hunt et al., 2013; Lin et al., 2013). Since clone library anlaysis demonstrated that HLII and LLIV were the dominant Prochlorococcus ecotypes in the Luzon Strait, we quantified their 23S rRNA contents using an RT-qPCR approach. As illustrated by Fig. 3b for samples collected from St. DC01, the estimated cellular rRNA contents were $150-270$ copies cell $^{-1}$ for HLII, and $\sim 500$ copies cell $^{-1}$ for LLIV. Within the euphotic zone, HLII exhibited increasing cellular rRNA with depth (maximum at $150 \mathrm{~m}$ ), perhaps reflective of cell size increase, while below the euphotic zone, HLII maintained a significant amount of rRNA at $300 \mathrm{~m}$ $\left(\sim 150\right.$ copies cell $\left.^{-1}\right)$ and LLIV cellular rRNA was below the limit of detection. Although the fluctuations of cellular rRNA content depend not only on the physiological condition of the cell but also the ecological niche or environmental conditions, our observation suggests that deep Prochlorococcus cells were intact and were possibly viable in the dark (Pernthaler et al., 2001; Steglich et al., 2010).

Cell digestion assay has shown that Prochlorococcus has a higher capacity to survive at low irradiance than Synechococcus (Agustí, 2004). In terms of heterotrophic potentials, although Prochlorococcus is not as well documented as
Synechococcus that is believed to have ectoproteolytic activities (Martinez and Azam, 1993; Moore et al., 2002; Cottrell and Kirchman, 2009), it has been reported that Prochlorococcus can incorporate exogenous organic nutrients (Moore et al., 2002; Zubkov et al., 2003; Zubkov and Tarran, 2005; Martinez et al., 2012), and oligopeptide transporters are found in the genomes of Prochlorococcus strains (Rocap et al., 2003). Prochlorococcus could also be partially heterotrophic (Muñoz-Marín et al., 2013). However, there has been no direct evidence for complete heterotrophic growth of Prochlorococcus and the genomic analysis did not reveal known pathways that would allow complete heterotrophy (Johnson et al., 1999; Rocap et al., 2003). Particularly, in the deep waters, exogenous organic compounds are unlikely to meet the energy and carbon demands of deep Prochlorococcus due to the restricted availability of labile dissolved organic matters, as most of the dissolved organic matters in the deep sea are refractory (Hansell et al., 2009; Jiao et al., 2010). Therefore catabolizing cellular storage of endogenous carbon sources such as carbohydrates and lipids would likely be a more possible mechanism for the deep Prochlorococcus to keep prolonged survival in the dark, as has been reported on other cyanobacteria (Osanai et al., 2005; Montechiaro et al., 2006).

\subsection{Possible mechanisms for the transportation of the deep Prochlorococcus in the Luzon Strait}

Previous studies have observed the presence of cyanobacterial cells or aggregates in the deep seas, which are usually attributed to sinking processes through phytodetritus, aggregation, and mesozooplankton grazing (Lochte and Turley, 1988; Richardson and Jackson, 2007). Some occasional observations of cyanobacteria in mesopelagic waters are attributed to winter deep convection (Vilibić and Šantić, 2008). Obviously all the above mechanisms cannot be simply applied to our case. Active physical transportation is most likely to be responsible for such a case. It is known that mesoscale eddies are present in the Luzon Strait area year-round (Yuan, 2002; Yuan et al., 2007). As seen from sea level anomalies (SLA) observed by satellite altimeters, strong cyclonic and anticyclonic eddies are present in the study area (Su, 2004; Yuan et al., 2006). During the study period from 21 March 2010 to 10 July 2011, the standard deviation of the weekly Aviso altimeter SLA averaged in the central Luzon area $\left(19^{\circ} 00^{\prime}-21^{\circ} 00^{\prime} \mathrm{N}, 119^{\circ} 30^{\prime}-121^{\circ} 30^{\prime} \mathrm{E}\right)$ was $8.7 \mathrm{~cm}$ (Fig. S7 shows a case of SLA on 21 April 2010). In addition to anticyclonic eddies leading to downwelling transport at the center of the eddies, cyclonic eddies can induce much stronger vertical transport by the interfacial Ekman transport along isopycnal surfaces at their rims. According to the classical Ekman theory, the average velocity across the Ekman layer thickness ( $1 / 2$ of the horizontal geostrophic velocity) was frequently above $0.5 \mathrm{~m} \mathrm{~s}^{-1}$ at the rims of the eddies, which is high enough to induce strong interfacial Ekman 


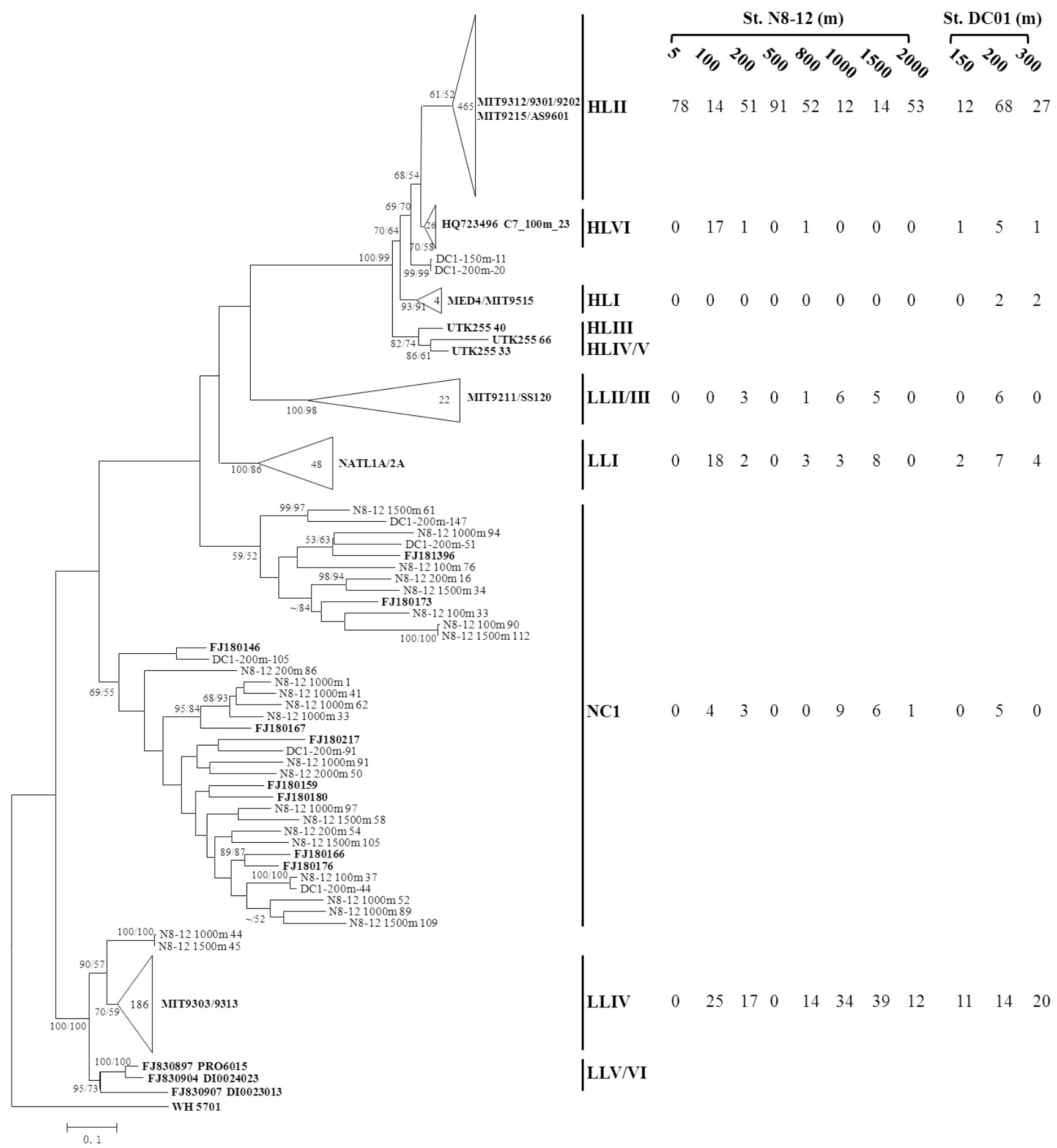

Fig. 4. Phylogenetic tree based on Prochlorococcus ITS sequences (without two tRNAs) from the western Pacific Ocean (St. N8-12 and St. DC01) showing that both high-light and low-light ecotypes of Prochlorococcus were present in samples from the aphotic waters. Support values, with 1000/100 replicates for NJ and ML analyses, were shown in the order of NJ/ML at nodes (values lower than $50 \%$ are not shown). The numbers of environmental sequences recovered in this research were shown in the triangles. Cultivated strains and environmental sequences from previous studies were shown in bold. Scale bar indicates 0.01 nucleotide substitutions per site. The numbers of sequences of each ecotype are indicated. 

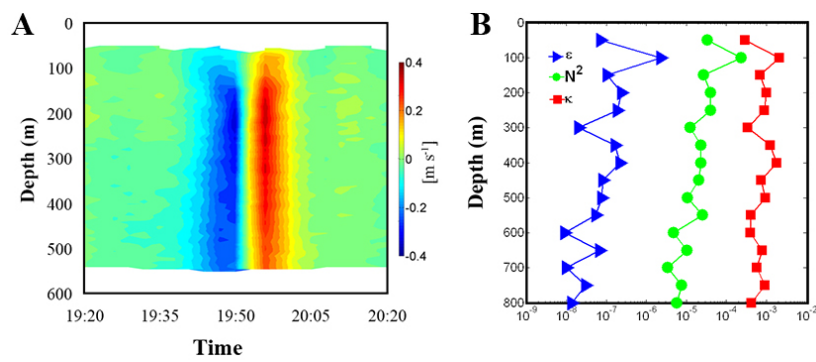

Fig. 5. Physical transportation mechanisms of Prochlorococcus in the Luzon Strait. (A) A case (31 March 2010) of the 384 solitons observed from 21 March 2010 to 20 April 2011 at $21^{\circ} 00^{\prime} \mathrm{N}$, $119^{\circ} 00^{\prime} \mathrm{E}$, showing the distribution of the vertical movement. (B) A case (28 March 2010) of the observed water column mixing at $21^{\circ} 02^{\prime} \mathrm{N}, 119^{\circ} 21^{\prime} \mathrm{E}$. $\varepsilon$ indicates the dissipation rate of turbulent kinetic energy $\left(\mathrm{W} \mathrm{kg}^{-1}\right), \mathrm{N}^{2}$ the buoyancy frequency square $\left(\mathrm{s}^{-2}\right)$, and $\kappa$ the mixing rate $\left(\mathrm{m}^{2} \mathrm{~s}^{-1}\right.$, at around $10^{-3} \mathrm{~m}^{2} \mathrm{~s}^{-1}, 100$-fold the oceanic background mixing).

transport (Yuan et al., 2007). For an isopycnal with a slope of $10^{-2}$, the descending of surface water parcels across the depth of $\sim 1000 \mathrm{~m}$ via the interfacial Ekman transport can be achieved within a few days (Dillon, 1982). Diapycnal mixing associated with internal waves, tides, meso-scale eddies and other processes plays a significant role in exchanging materials between the upper and lower layers (Yuan, 2002; Tian et al., 2009). In particular, a special type of internal wave called a soliton can induce rapid vertical water movement and exchange (Jackson and Apel, 2002). Solitons occurred almost daily in the Luzon Strait area (particularly on the western side). For example, 384 internal solitons were observed during the period from 21 March 2010 to 20 April 2011 by an ADCP deployed at $21^{\circ} 00^{\prime} \mathrm{N}, 119^{\circ} 00^{\prime} \mathrm{E}$ (Fig. S3). The amplitudes of some of the observed thermocline depressions of the internal solitons were as large as $170 \mathrm{~m}$. The recorded vertical velocity at $550 \mathrm{~m}$ has reached $0.25 \mathrm{~m} \mathrm{~s}^{-1}$ (at $21^{\circ} 00^{\prime} \mathrm{N}$, $119^{\circ} 00^{\prime}$ E; Fig. 5a). Combined with the large vertical diffusivity in the area, the solitons could induce deep mixing overcoming the thermocline barriers at about $100 \mathrm{~m}$ depth (e.g., Fig. 5b). Thus the rapid vertical water movements could effectively push Prochlorococcus cells down and turbulence then acts to keep some of the cells in the deep water.

Unlike the common water column mixing processes that usually reduce the populations of Prochlorococcus in the euphotic zone (Post, 2006), the reciprocating depression and elevation waves of the internal solitons (Zhao et al., 2004a) mainly took place in the lower euphotic zone and below, with each cycle lasting for a short time (about $30 \mathrm{~min}$ for the main pulse and 2 hours for the following associates) in the case of the Luzon Strait (Figs. 5 and S8). The rapid vertical water movements could regularly transport a certain amount of Prochlorococcus cells from nutrient-depleted euphotic waters to nutrient-replete deep waters, allowing the cells to access sufficient inorganic nutrients, and subsequently bring a fraction of the cells back to the euphotic zone for efficient photosynthesis and carbon fixation. This could provide the Prochlorococcus cells with opportunities to access temporally and spatially alternating light and nutrient conditions, overall supporting higher production in the euphotic zone (up to $10^{5}$ cells $\mathrm{ml}^{-1}$ ) and longer survival in the aphotic waters (so as to be observable). Meanwhile, each solitary wave cycle releases a certain portion of the Prochlorococcus cells into the dark ocean, acting as a vertical conveyer belt for picoplankton export (Fig. S8). It is worth noting that other microbial components (e.g., phytoplankton) may also be transported, but Prochlorococcus would be the most influenced, given that they are naturally dominating in the lower euphotic zone where the momentum of internal solitary waves is the maximum.

\subsection{Implications of deep Prochlorococcus in ocean carbon cycling and future work}

The abundances of the deep Prochlorococcus we observed are typically about one to two orders of magnitude lower than the maximum abundance (i.e., lower euphotic zone) but are comparable to the abundance in the upper part of the euphotic zone in the Luzon Strait areas. If such a distribution pattern of Prochlorococcus is in normal balanced status, that is, the total number of the observed deep Prochlorococcus cells in the $200-800 \mathrm{~m}$ water layer would count for up to $15 \%$ of the total standing abundance of Prochlorococcus in the upper $200 \mathrm{~m}$ layer. Given that the dead cells may not have been included in our FCM observation, the real export rate of Prochlorococcus could be even higher. Transportation of Prochlorococcus and other microbes from the surface to deeper waters constitutes a vertical carbon flux, which might contribute to the relatively high organic carbon pool observed in intermediate waters of the South China Sea (most profiles from sites close to the Luzon Strait) (Dai et al., 2009). Deep Prochlorococcus would also contribute to dissolved organic carbon (DOC) through passive leakage and viral lysis (Suttle, 2005). Heterotrophic bacteria and archaea would consequently take up the labile DOC and transform part of it to refractory DOC through the microbial carbon pump, constituting long-term carbon storage in the ocean (Jiao et al., 2010). Although it is too early to evaluate the biogeochemical role of deep Prochlorococcus on a global scale, which need more field observations, our finding of the substantial presence of the intact Prochlorococcus cells in the aphotic waters of the study areas suggests a novel mechanism for rapid vertical transportation of picoplankton carbon other than previously reported mechanisms (Lochte and Turley, 1988; Richardson and Jackson, 2007; Vilibić and Šantić, 2008), and raises fundmental questions about the ecology of Prochlorococcus for future studies, such as: how long can Prochlorococcus cells survive in dark oceans where nutrients are replete but temperatures are low?; does any gene mutation, regulation of gene expression or physiological adaptation exist in the dark 
ocean (given that the physical transportation is occurring successively)?; and what are the fates of these Prochlorococcus cells and the ecological consequences (food web dynamics, grazing, viral lysis, and their impacts on carbon expert)?, etc. The substantial presence of Prochlorococcus in the dark ocean reported here and the proposed mechanisms bring new insights and call for further studies on mechanisms of carbon cycling and carbon sequestration in the ocean.

Acknowledgements. The authors thank Penny Chisholm, Jonathan Zehr, Gerhard Herndl, Carol Robinson, Dennis Hansel, Craig Carlson and Louis St Lawrence for their valuable comments; Qiang Zheng, Sijun Huang, Xiaodong Huang, Zhimin Jian, Fan Wang and crew members of the R/Vs Dongfanghong-2 and Kexue-1 for their assistance in the lab and in the field. This work was supported by MOST, SOA and NSFC (2013CB955700, 2011CB808800, 2012AA092003, GASI-03-01-02-05, 91028001, 40890151, 40888001, 2008AA09A402, 2012CB956000) and US-NSF (1031064).

Edited by: C. Robinson

\section{References}

Agustí, S.: Viability and niche segregation of Prochlorococcus and Synechococcus cells across the Central Atlantic Ocean, Aquat. Microb. Ecol., 36, 53-59, 2004.

Ahlgren, N. A., Rocap, G., and Chisholm, S. W.: Measurement of Prochlorococcus ecotypes using real-time polymerase chain reaction reveals different abundances of genotypes with similar light physiologies, Environ. Microbiol., 8, 441-454, 2006.

Alford, M. H., Lien, R. C., Simmons, H., Klymak, J., Ramp, S., Yang, Y. J., Tang, D., and Chang, M. H.: Speed and evolution of nonlinear internal waves transiting the South China Sea, J. Phys. Oceanogr., 40, 1338-1355, 2010.

Cai, H., Wang, K., Huang, S., Jiao, N., and Chen, F.: Distinct patterns of picocyanobacterial communities in winter and summer in the Chesapeake Bay, Appl. Environ. Microb., 76, 2955-2960, 2010.

Coleman, M. L. and Chisholm, S. W.: Code and context: Prochlorococcus as a model for cross-scale biology, Trends Microbiol., 15, 398-407, 2007.

Cottrell, M. T. and Kirchman, D. L.: Photoheterotrophic microbes in the Arctic Ocean in summer and winter, Appl. Environ. Microb., 75, 4958-4966, 2009.

Dai, M., Meng, F., Tang, T., Kao, S.-J., Lin, J., Chen, J., Huang, J.C., Tian, J., Gan, J., and Yang, S.: Excess total organic carbon in the intermediate water of the South China Sea and its export to the North Pacific, Geochem. Geophy. Geosy., 10, Q12002, doi:10.1029/2009GC002752, 2009.

DeLong, E. F., Preston, C. M., Mincer, T., Rich, V., Hallam, S. J., Frigaard, N. U., Martinez, A., Sullivan, M. B., Edwards, R., Brito, B. R., Chisholm, S. W., and Karl, D. M.: Community genomics among stratified microbial assemblages in the ocean's interior, Science, 311, 496-503, 2006.
Dillon, T. M.: Vertical overturns: a comparison of Thorpe and Ozmidov length scales, J. Geophys. Res., 87, 9601-9613, 1982.

Finnigan, T. D., Luther, D. S., and Lukas, R.: Observations of enhanced diapycnal mixing near the Hawaiian Ridge, J. Phys. Oceanogr., 32, 2988-3002, 2002.

Fuhrman, J. A., Comeau, D. E., Hagstrom, A., and Chan, A. M.: Extraction from natural planktonic microorganisms of DNA suitable for molecular biological studies, Appl. Environ. Microbiol., 54, 1426-1429, 1988.

Glibert, P. M., Heil, C. A., Hollander, D. J., Revilla, M., Hoare, A., Alexander, J., and Murasko, S.: Evidence for dissolved organic nitrogen and phosphorus uptake during a cyanobacterial bloom in Florida Bay, Mar. Ecol-prog. Ser., 280, 73-83, 2004.

Hansell, D. A., Carlson, C. A., Repeta, D. J., and Schlitzer, R.: Dissolved organic matter in the ocean: a controversy stimulates new insights, Oceanography, 22, 202-211, 2009.

Honda, M. C., Imai, K., Nojiri, Y., Hoshi, F., Sugawara, T., and Kusakabe, M.: The biological pump in the northwestern North Pacific based on fluxes and major components of particulate matter obtained by sediment-trap experiments (1997-2000), DeepSea Res. Pt. II, 49, 5595-5625, 2002.

Hunt, D. E., Lin, Y., Church, M. J., Karl, D. M., Tringe, S. G., Izzo, L. K., and Johnson, Z. I.: Relationship between abundance and specific activity of bacterioplankton in open ocean surface waters, Appl. Environ. Microb., 79, 177-184, 2013.

Huang, S., Wilhelm, S. W., Harvey, H. R., Taylor, K., Jiao, N. and Chen, F.: Novel lineages of Prochlorococcus and Synechococcus in the global oceans, ISME J, 6, 285-297, 2011.

Jackson, C. R. and Apel, J. R.: An atlas of internal solitary-like waves and their properties, Global Ocean Associates, Rockville, 2002.

Jackson, G. A., Waite, A. M., and Boyd, P. W.: Role of algal aggregation in vertical carbon export during SOIREE and in other low biomass environments, Geophys. Res. Lett., 32, L13607, doi:10.1029/2005GL023180, 2005.

Jan, S. and Chen, C.-T. A.: Potential biogeochemical effects from vigorous internal tides generated in Luzon Strait: a case study at the southernmost coast of Taiwan, J. Geophys. Res., 114, C04021, doi:10.1029/2008JC004887, 2009.

Jan, S., Chern, C.-S., Wang, J., and Chao, S.-Y.: Generation of diurnal K1 internal tide in the Luzon Strait and its influence on surface tide in the South China Sea, J. Geophys. Res., 112, C06019, doi:10.1029/2006JC004003, 2007.

Jia, Y. and Liu, Q.: Eddy shedding from the Kuroshio bend at Luzon Strait, J. Oceanogr., 60, 1063-1069, 2004.

Jiao, N., Herndl, G. J., Hansell, D. A., Benner, R., Kattner, G., Wilhelm, S. W., Kirchman, D. L., Weinbauer, M. G., Luo, T., Chen, F., and Azam, F.: Microbial production of recalcitrant dissolved organic matter: long-term carbon storage in the global ocean, Nat. Rev. Microbiol., 8, 593-599, 2010.

Jiao, N., Herndl, G. J., Hansell, D. A., Benner, R., Kattner, G., Wilhelm, S. W., Kirchman, D. L., Weinbauer, M. G., Luo, T., Chen, F., and Azam, F.: The microbial carbon pump and the oceanic recalcitrant dissolved organic matter pool, Nat. Rev. Microbiol., 9, 555-555, 2011.

Johnson, Z. I., Landry, M. L., Bidigare, R. R., Brown, S. L., Campbell, L., Gunderson, J., Marra, J., and Trees, C.: Energetics and growth kinetics of a deep Prochlorococcus spp. population in the Arabian Sea, Deep-Sea Res. Pt. II, 46, 1719-1743, 1999. 
Johnson, Z. I., Zinser, E. R., Coe, A., McNulty, N. P., Woodward, E. M., and Chisholm, S. W.: Niche partitioning among Prochlorococcus ecotypes along ocean-scale environmental gradients, Science, 311, 1737-1740, 2006.

Kan, J., Crump, B., Wang, K., and Chen, F.: Bacterioplankton community in Chesapeake Bay: predictable or random assemblages, Limnol. Oceanogr., 51, 2157-2169, 2006.

Larkin, M. A., Blackshields, G., Brown, N. P., Chenna, R., McGettigan, P. A., McWilliam, H., Valentin, F., Wallace, I. M., Wilm, A., Lopez, R., Thompson, J. D., Gibson, T. J., and Higgins, D. G.: Clustal W and Clustal X version 2.0, Bioinformatics, 23, 29472948, 2007.

Lavin, P., González, B., Santibáñez, J. F., Scanlan, D. J., and Ulloa, O.: Novel lineages of Prochlorococcus thrive within the oxygen minimum zone of the eastern tropical South Pacific, Environ. Microb. Reports, 2, 728-738, 2010.

Laurent, L. S.: Turbulent dissipation on the margins of the South China Sea, Geophys. Res. Lett., 35, L23615, doi:10.1029/2008GL035520, 2008.

Lin, Y., Gazsi, K., Lance, V. P., Larkin, A. A., Chandler, J. W., Zinser, E. R., and Johnson, Z. I.: In situ activity of a dominant Prochlorococcus ecotype (eHL-II) from rRNA content and cell size, Environ. Microbiol., 15, 2736-2747, 2013.

Lochte, K. and Turley, C. M.: Bacteria and cyanobacteria associated with phytodetritus in the deep sea, Nature, 333, 67-69, 1988.

Marie, D., Partensky, F., Vaulot, D., and Brussaard, C.: Enumeration of phytoplankton, bacteria, and viruses in marine samples, in: Current Protocols in Cytometry, edited by: Robinson, J. P., Darzynkiewicz, Z., Hoffman, R., Nolan, J., Rabinovitch, P., Watkins, S., Dean, P. N., Dobrucki, J., Dressler, L. G., Orfao, A., Stewart, C. C., Tanke, H. J., and Wheeless, L. L., John Wiley \& Sons Inc, New York, 11.11.11-11.11.15, 1999.

Martinez, A., Osburne, M. S., Sharma, A. K., DeLong, E. F., and Chisholm, S. W.: Phosphite utilization by the marine picocyanobacterium Prochlorococcus MIT9301, Environ. Microbiol., 14, 1363-1377, 2012.

Martinez, J., and Azam, F.: Aminopeptidase activity in marine chroococcoid cyanobacteria, Appl. Environ. Microb., 59, 37013707, 1993.

Martiny, A. C., Tai, A. P. K., Veneziano, D., Primeau, F., and Chisholm, S. W.: Taxonomic resolution, ecotypes and the biogeography of Prochlorococcus, Environ. Microbiol., 11, 823832, 2009

Montechiaro, F., Hirschmugl, C. J., Raven, J. A., and Giordano, M.: Homeostasis of cell composition during prolonged darkness, Plant Cell Environ., 29, 2198-2204, 2006.

Moore, L. R., Post, A. F., Rocap, G., and Chisholm, S. W.: Utilization of different nitrogen sources by the marine cyanobacteria Prochlorococcus and Synechococcus, Limnol. Oceanogr., 47, 989-996, 2002.

Muñoz-Marín, M. C., Luque, I., Zubkov, M. V., Hill, P. G., Diez, J. and García-Fernández, J. M.: Prochlorococcus can use the Pro1404 transporter to take up glucose at nanomolar concentrations in the Atlantic Ocean, P. Natl. Acad. Sci., 110, 8597-8602, 2013.

Osanai, T., Kanesaki, Y., Nakano, T., Takahashi, H., Asayama, M., Shirai, M., Kanehisa, M., Suzuki, I., Murata, N., and Tanaka, K.: Positive regulation of sugar catabolic pathways in the cyanobac- terium Synechocystis sp. PCC 6803 by the group $2 \sigma$ factor sigE, J. Biol. Chem., 280, 30653-30659, 2005.

Partensky, F., Hess, W. R., and Vaulot, D.: Prochlorococcus, a marine photosynthetic prokaryote of global significance, Microbiol Mol. Biol. R., 63, 106-127, 1999.

Partensky, F. and Garczarek, L.: Prochlorococcus: advantages and limits of minimalism, Annu. Rev. Mar. Sci., 2, 305-331, 2010.

Pernthaler, A., Pernthaler, J., Eilers, H., and Amann, R.: Growth patterns of two marine isolates: adaptations to substrate patchiness? Appl. Environ. Microbiol., 67, 4077-4083, 2001.

Post, A. F.: The genus Prochlorococcus, Prokaryotes, 4, 1099-1110, 2006.

Richardson, T. L. and Jackson, G. A.: Small phytoplankton and carbon export from the surface ocean, Science, 315, 838-840, 2007.

Rocap, G., Larimer, F. W., Lamerdin, J., Malfatti, S., Chain, P., Ahlgren, N. A., Arellano, A., Coleman, M., Hauser, L., Hess, W. R., Johnson, Z. I., Land, M., Lindell, D., Post, A. F., Regala, W., Shah, M., Shaw, S. L., Steglich, C., Sullivan, M. B., Ting, C. S., Tolonen, A., Webb, E. A., Zinser, E. R., and Chisholm, S. W.: Genome divergence in two Prochlorococcus ecotypes reflects oceanic niche differentiation, Nature, 424, 1042-1047, 2003.

Six, C., Thomas, J. C., Brahamsha, B., Lemoine, Y., and Partensky, F.: Photophysiology of the marine cyanobacterium Synechococcus sp. WH8102, a new model organism, Aquat. Microb. Ecol., 35, 17-29, 2004.

Sohrin, R., Isaji, M., Obara, Y., Agostini, S., Suzuki, Y., Hiroe, Y., Ichikawa, T., and Hidaka, K.: Distribution of Synechococcus in the dark ocean, Aquat. Microb. Ecol., 64, 1-14, 2011.

Steglich, C., Lindell, D., Futschik, M., Rector, T., Steen, R., and Chisholm, S. W.: Short RNA half-lives in the slow-growing marine cyanobacterium Prochlorococcus, Genome Biol., 11, R54, doi:10.1186/gb-2010-11-5-r54, 2010.

$\mathrm{Su}$, J.: Overview of the South China Sea circulation and its influence on the coastal physical oceanography outside the Pearl River Estuary, Cont. Shelf. Res., 24, 1745-1760, 2004.

Suttle, C. A.: Viruses in the sea, Nature, 437, 356-361, 2005.

Tamura, K., Dudley, J., Nei, M., and Kumar, S.: MEGA4: Molecular Evolutionary Genetics Analysis (MEGA) software version 4.0, Mol. Biol. Evol., 24, 1596-1599, 2007.

Tian, J., Yang, Q., Liang, X., Xie, L., Hu, D., Wang, F., and Qu, T.: Observation of Luzon Strait transport, Geophys. Res. Lett., 33, L19607, doi:10.1029/2006GL026272, 2006.

Tian, J., Yang, Q., and Zhao, W.: Enhanced diapycnal mixing in the South China Sea, J. Phys. Oceanogr., 39, 3191-3203, 2009.

Vanucci, S., Dell'Anno, A., Pusceddu, A., Fabiano, M., Lampitt, R. S., and Danovaro, R.: Microbial assemblages associated with sinking particles in the Porcupine Abyssal Plain (NE Atlantic Ocean), Prog. Oceanogr., 50, 105-121, 2001.

Vilibić, I. and Šantić, D.: Deep water ventilation traced by Synechococcus cyanobacteria, Ocean Dynam., 58, 119-125, 2008.

Yamaguchi, A., Watanabe, Y., Ishida, H., Harimoto, T., Furusawa, K., Suzuki, S., Ishizaka, J., Ikeda, T., and Takahashi, M. M.: Structure and size distribution of plankton communities down to the greater depths in the western North Pacific Ocean, Deep-Sea Res. Pt. II, 49, 5513-5529, 2002.

Yamaguchi, A., Watanabe, Y., Ishida, H., Harimoto, T., Furusawa, K., Suzuki, S., Ishizaka, J., Ikeda, T., and Takahashi, M. M.: Latitudinal differences in the planktonic biomass 
and community structure down to the greater depths in the western North Pacific, J. Oceanogr., 60, 773-787, 2004.

Yool, A., Martin, A. P., Fernández, C., and Clark, D. R.: The significance of nitrification for oceanic new production, Nature, 447, 999-1002, 2007.

Yuan, D.: A numerical study of the South China Sea deep circulation and its relation to the Luzon Strait transport, Ac. Oceanol. Sin., 21, 187-202, 2002.

Yuan, D., Han, W., and Hu, D.: Surface Kuroshio path in the Luzon Strait area derived from satellite remote sensing data, J. Geophys. Res., 111, C11007, doi:10.1029/2005JC003412, 2006.

Yuan, D., Han, W., and Hu, D.: Anti-cyclonic eddies northwest of Luzon in summer-fall observed by satellite altimeters, Geophys. Res. Lett., 34, L13610, doi:10.1029/2007GL029401, 2007.

Zhao, Z., Klemas, V., Zheng, Q., Li, X., and Yan, X.-H.: Estimating parameters of a two-layer stratified ocean from polarity conversion of internal solitary waves observed in satellite SAR images, Remote Sens. Environ., 92, 276-287, 2004a.
Zhao, Z., Klemas, V., Zheng, Q., and Yan, X.-H.: Remote sensing evidence for baroclinic tide origin of internal solitary waves in the northeastern South China Sea, Geophys. Res. Lett., 31, 1-4, 2004b.

Zinser, E. R., Coe, A., Johnson, Z. I., Martiny, A. C., Fuller, N. J., Scanlan, D. J., and Chisholm, S. W.: Prochlorococcus ecotype abundances in the North Atlantic Ocean as revealed by an improved quantitative PCR method, Appl. Environ. Microb., 72, 723-732, 2006.

Zubkov, M. V. and Tarran, G. A.: Amino acid uptake of Prochlorococcus spp. in surface waters across the South Atlantic Subtropical Front, Aquat. Microb. Ecol., 40, 241-249, 2005.

Zubkov, M. V., Fuchs, B. M., Tarran, G. A., Burkill, P. H., and Amann, R.: High rate of uptake of organic nitrogen compounds by Prochlorococcus cyanobacteria as a key to their dominance in oligotrophic oceanic waters, Appl. Environ. Microb., 69, 12991304, 2003. 